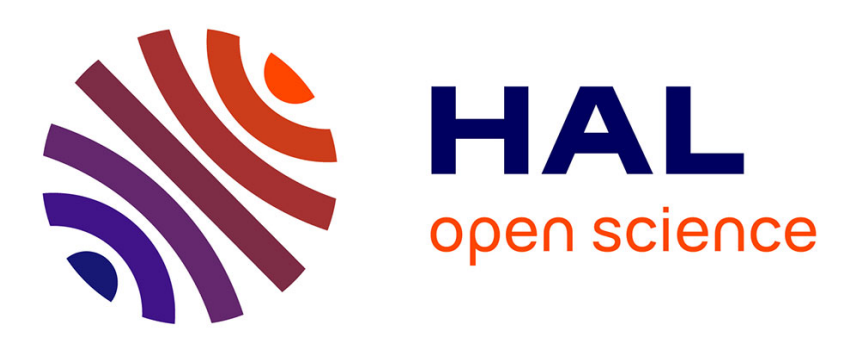

\title{
Which individuals become fatter when they practice exercise?
}

Jean-Frédéric Brun, J. Romain, A. Sferlazza, Christine Fédou, E. Raynaud, Jacques Mercier

\section{To cite this version:}

Jean-Frédéric Brun, J. Romain, A. Sferlazza, Christine Fédou, E. Raynaud, et al.. Which individuals become fatter when they practice exercise?. Science \& Sports, 2016, 31 (4), pp.214 - 218. 10.1016/j.scispo.2016.06.001 . hal-01803460

\section{HAL Id: hal-01803460 \\ https://hal.umontpellier.fr/hal-01803460}

Submitted on 30 Nov 2019

HAL is a multi-disciplinary open access archive for the deposit and dissemination of scientific research documents, whether they are published or not. The documents may come from teaching and research institutions in France or abroad, or from public or private research centers.
L'archive ouverte pluridisciplinaire HAL, est destinée au dépôt et à la diffusion de documents scientifiques de niveau recherche, publiés ou non, émanant des établissements d'enseignement et de recherche français ou étrangers, des laboratoires publics ou privés. 


\title{
Which individuals become fatter when they practice exercise?
}

\section{Quels sont les patients que l'activité physique fait grossir?}

\author{
J.-F. Brun*, A.J. Romain, A. Sferlazza, C. Fédou, \\ E. Raynaud de Mauverger, J. Mercier
}

UMR CNRS 9214, Inserm U1046 «physiologie et médecine expérimentale du cœur et des muscles [PHYMEDEXP] », université de Montpellier, 34090 Montpellier cedex, France

\section{KEYWORDS \\ Obesity; \\ Exercise; \\ Training; \\ Lipid oxidation; \\ LIPOXmax; \\ Weight loss}

\begin{abstract}
Summary
Introduction. - It is well established that high volumes (15-20 h/week) of physical activity at intensities $>60 \% \mathrm{VO}_{2 \max }$, as well as low volumes ( $2-3 \mathrm{hrs} / \mathrm{wk}$ ) of low intensity exercise targeted in the zone of the LIPOXmax (around $40 \% \mathrm{VO}_{2 \max }$ ) allow a significant and prolonged loss of fat mass. By contrast it is not uncommon to observe patients whose fat mass increases when they practice low volumes of activity at intensity around or above $60 \% \mathrm{VO}_{2 \max }$. This paradoxical situation has surprisingly retained little attention. This study aimed at characterizing these patients.

Methods. - Over 2 years we observed and investigated 26 patients ( 5 men and 13 women) aged 21 to 69 who gained weight when they began to engage in physical activity. They weighed 62 to $144 \mathrm{~kg}$. These patients achieved an exercise calorimetry and segmental impedance and we compared to 15 matched subjects ( 2 men and 13 women) who gradually lose weight with a protocol of physical activity at low to moderate intensity.

Results. - There are no differences in body composition. Exercise calorimetry evidences that the ability of these subjects to oxidize lipid was both significantly lower $(8.10 \pm 0.49$ vs $10.8 \pm 1.04 \mathrm{mg} / \mathrm{min} / \mathrm{kg}$ of muscle, $P<0.02$ ) and shifted towards a lower power intensity $(36.43 \pm 2.64$ vs $47.16 \pm 4.77$ watts, $P=0.05$ ). The level where there is no longer lipid oxidation and an exclusive use of carbohydrates also occurs in these subjects at a lower intensity $\left(61.7 \pm 3.1 \%\right.$ vs $\left.75.18 \pm 5.90 \% \mathrm{VO}_{2 \max }, P<0.05\right)$. All these patients that gain weight during exercise training perform low volumes $(2-3 \mathrm{~h} / \mathrm{wk})$ of exercise that are clearly targeted above the lipid oxidation zone. These subjects describe feelings of increased hunger after exercise, with or without binging and nibbling. When exercise is performed immersed in water it also appears to stimulate appetite and to result in weight gain in some individuals.
\end{abstract}


Conclusion. - Therefore, paradoxical weight gain due to low volume of exercise at $>60 \% \mathrm{VO}_{2 \max }$ is not uncommon, although it seems a priori illogical and is thus largely ignored. It seems to be primarily determined by a targeting above the area of lipid oxidation, resulting into orexigenic falls in blood glucose, mostly in subjects that are low fat oxidizers. The glucose lowering effect of exercise performed in water may also favor this mechanism.

(c) 2016 Elsevier Masson SAS. All rights reserved.

\section{MOTS CLÉS}

Obésité ;

Exercice ;

Entraînement ;

Oxydation des

lipides ;

LIPOXmax ;

Perte de poids

\section{Résumé}

Introduction. - Plusieurs stratégies basées sur l'activité physique entraînent une perte de masse grasse importante et prolongée, qu'il s'agisse de hauts volumes $(15-20 \mathrm{~h} / \mathrm{sem})$ d'activité physique quelle qu'en soit l'intensité, ou de faibles volumes ( $2-3 \mathrm{~h} / \mathrm{sem}$ ) à faible intensité ciblés dans la zone d'oxydation maximale des lipides (LIPOXmax). On observe par contre des patients dont la masse grasse augmente lors de la pratique de faibles volumes d'activité d'intensité modérée à élevée $>60 \% \mathrm{VO}_{2 \max }$, et cette situation en apparence paradoxale a peu retenu l'attention. Ce sont ces sujets que nous avons voulu caractériser.

Matériels et méthodes. - Sur deux ans ont été observés et explorés 26 patients ( 5 hommes et 13 femmes) âgés de 21 à 69 ans qui ont pris du poids lorsqu'ils ont entrepris de pratiquer une activité physique. Ils pèsent 62 à $144 \mathrm{~kg}$. Ces patients ont réalisé une calorimétrie d'effort et une impédancemétrie segmentaire et nous les avons comparés à 15 sujets appariés ( 2 hommes et $13 \mathrm{femmes}$ ) qui maigrissent progressivement en réalisant un protocole d'activité physique régulière d'intensité faible à modérée.

Résultats. - Il n'y a pas de différence de composition corporelle. La calorimétrie d'effort objective une oxydation lipidique un peu moindre et décalée vers des puissances plus basses, culminant à $8,10 \pm 0,49$ vs $10,8 \pm 1,04 \mathrm{mg} / \mathrm{min} / \mathrm{kg}$ de muscle, $p<0,02$, à une puissance inférieure : $36,43 \pm 2,64$ vs $47,16 \pm 4,77$ watts, $p=0,05$, et s'annulant pour laisser place à une utilisation exclusive de glucides à $61,7 \pm 3,1 \%$ vs $75,18 \pm 5,90 \%$ vs de $\mathrm{VO}_{2 \max }, p<0,05$. Tous ces patients qui grossissent en faisant de l'exercice font en fait des volumes d'activité faibles ( $2-3 \mathrm{~h} / \mathrm{sem})$ ciblés nettement au dessus de la zone d'oxydation des lipides ainsi caractérisée. Ce ciblage est déterminé par l'influence des coachs des salles de gymnastique ou de par leur représentation personnelle particulière du «sport ». Ils décrivent des sensations de faim accrue après exercice, accompagnées ou non d'hyperphagie et de grignotages. Des exercices en milieu aquatique (piscine) semblent également être orexigènes et entraîner chez certaines personnes une prise de poids.

Conclusion. - Au total les prises de poids paradoxales lors de la pratique sportive de faible volume à $>60 \% \mathrm{VO}_{2 \max }$ ne sont pas rares bien que leur aspect a priori illogique les fasse largement méconnaître. Elles semblent essentiellement déterminées par un ciblage au dessus de la zone d'oxydation des lipides qui détermine des hypoglycémies orexigènes, notamment chez des sujets initialement faibles oxydeurs de lipides, et semblent favorisées par l'effet hypoglycémiant de l'exercice en milieu aquatique.

(c) 2016 Elsevier Masson SAS. Tous droits réservés.

\section{Introduction}

Exercise, which was until recently considered as a poorly efficient complement of diet for reducing weight loss, is now well recognized as an efficient treatment of obesity. It was classically supposed that its effect was totally explained by the amount of energy expenditure: accordingly, the recent RESOLVE study shows that high volumes $(15-20 \mathrm{~h} /$ week $)$ of physical activity at both high $\left(>60 \% \mathrm{VO}_{2 \max }\right)$ or low $(30-40 \%$ $\mathrm{VO}_{2 \max }$ ) intensity are a very efficient weight-reducing procedure [1]. On the other hand, there is an increasing body of literature demonstrating that low volumes $(2-3 \mathrm{hrs} / \mathrm{wk})$ of exercise targeted at low intensity at the level of the LIPOX$\max \left(40 \% \mathrm{VO}_{2 \max }\right)$ allow a significant and prolonged loss of fat mass [2]. By contrast it is not uncommon to observe patients whose fat mass actually increases when they engage into rather vigorous exercise sessions several times a week. Such a finding that seems paradoxical has until now retained very little attention. The aim of this paper is to describe these patients.

\section{Patients and methods}

\subsection{Subjects}

Over 2 years we observed and investigated 26 patients ( 5 men and 13 women) aged 21 to 69 years who gained weight when engaging in physical activity. Characteristics of these patients are shown of Table 1. Their initial weight ranged between 62 to 144 kilograms. These patients were compared to 15 matched subjects ( 2 men and 13 women) 
Table 1 Presentation of the two groups of patients.

\begin{tabular}{|c|c|c|c|c|c|c|c|c|c|c|}
\hline & $\begin{array}{l}\text { Gender } \\
(M / F)\end{array}$ & Age (years) & Weight (kg) & Height $(\mathrm{cm})$ & $\begin{array}{l}\text { Body mass } \\
\text { index }\left(\mathrm{kg} \cdot \mathrm{m}^{-2}\right)\end{array}$ & $\begin{array}{l}\text { Fat-free } \\
\text { mass }\end{array}$ & Muscle mass & $\%$ fat & $\begin{array}{l}\text { Waist circum- } \\
\text { ference }\end{array}$ & $\begin{array}{l}\text { Hip } \\
\text { circumference }\end{array}$ \\
\hline $\begin{array}{l}\text { Losing weight } \\
\qquad(n=15)\end{array}$ & $2 \mathrm{M} / 13 \mathrm{~F}$ & $46.67 \pm 3.76$ & $96.64 \pm 4.24$ & $166.17 \pm 2.13$ & $34.93 \pm 1.39$ & $56.28 \pm 2.62$ & $26.04 \pm 1.49$ & $0.42 \pm 0.01$ & $104.02 \pm 5.04$ & $115.15 \pm 2.18$ \\
\hline $\begin{array}{l}\text { Gaining weight } \\
\qquad(n=26)\end{array}$ & $5 \mathrm{M} / 13 \mathrm{~F}$ & $51.77 \pm 4.15$ & $93.70 \pm 4.98$ & $162.38 \pm 1.62$ & $35.55 \pm 1.90$ & $53.24 \pm 1.65$ & $22.21 \pm 0.97$ & $0.42 \pm 0.02$ & $107.85 \pm 6.11$ & $117.31 \pm 4.62$ \\
\hline Comparison & NS & NS & NS & NS & NS & NS & NS & NS & NS & NS \\
\hline
\end{tabular}


who lose weight gradually by making a low to moderate intensity physical activity protocol regularly. As shown in Table 1, there are no differences in body composition.

\subsection{Bioelectrical impedance measurements}

Prior to the exercise-test, subjects' body composition was assessed with bioimpedance analysis with a six terminal impedance plethismograph BIACORPUS RX 4000 Biacorpus RX4000, (Healthnesslink, 8, avenue Jean-Jaurès, 92130 Issyles-Moulineaux, France) with data analysis with the software BodyComp 8.4. This device measures total resistance of the body to an alternative electric current of $50 \mathrm{kHz}$.

\subsection{Exercise calorimetry}

All subjects were asked to come and perform test in the morning after an overnight fast (12 hours). The test consisted of five to six minutes steady-state workloads theoretically set at 20,30,40,50, and $60 \%$ of Pmax. However these intensity levels can be modified during the test according to the evolution of the respiratory exchange ratio $\left(\mathrm{RER}=\mathrm{VCO}_{2} / \mathrm{VO}_{2}\right)$ in order to obtain values of $\mathrm{RER}$ below and above 0.9 which is the level of the Crossover Point (COP) which is defined below. The subjects performed the test on an electromagnetically braked cycle ergometer (Ergoline Bosch 500). Heart rate and electrocardiographic parameters were monitored continuously throughout the test by standard 12-lead procedures. Metabolic and ventilatory responses were assessed using a digital computer based breath to breath exercise analyzing system (Jaeger $M S-C P X$ ). Thus, we could measure $\mathrm{VO}_{2}, \mathrm{VCO}_{2}$ (in $\mathrm{mL} / \mathrm{min}$ ) and calculate the non-protein RER. Lipid oxidation (lipox) and carbohydrate utilization (glucox) rates were calculated by indirect calorimetry from gas exchange measurements according to the non-protein respiratory quotient technique as previously reported [2]. This technique provided carbohydrate and lipid oxidation rates at different exercise intensities. Additionally, after smoothing the curves, we calculated the two parameters quantifying the balance between carbohydrates and lipids induced by increasing exercise intensity: the maximal lipid oxidation point (LIPOXmax) and the Crossover Point (COP). The LIPOXmax is the exercise intensity at which lipid oxidation reaches its maximal level before decreasing while carbohydrate utilization further increases. It is calculated as previously reported after smoothing of the curve plotting lipid oxidation as a function of power. The maximal lipid oxidation rate at the LIPOXmax was expressed in $\mathrm{mg} \cdot \mathrm{kg}^{-1} \cdot \mathrm{min}^{-1}$. The crossover point (COP) is the exercise intensity at which the part of carbohydrate utilization used to provide energy becomes predominant over lipid oxidation. Beyond this point, the subject is referred to as "glucodependent"'. It was calculated as the exercise intensity where $70 \%$ of the substrates used to provide energy are carbohydrates and $30 \%$ are lipids.

\section{Results}

As shown on Fig. 1, exercise calorimetry evidences that the ability to oxidize lipids at exercise is slightly lowered (peak
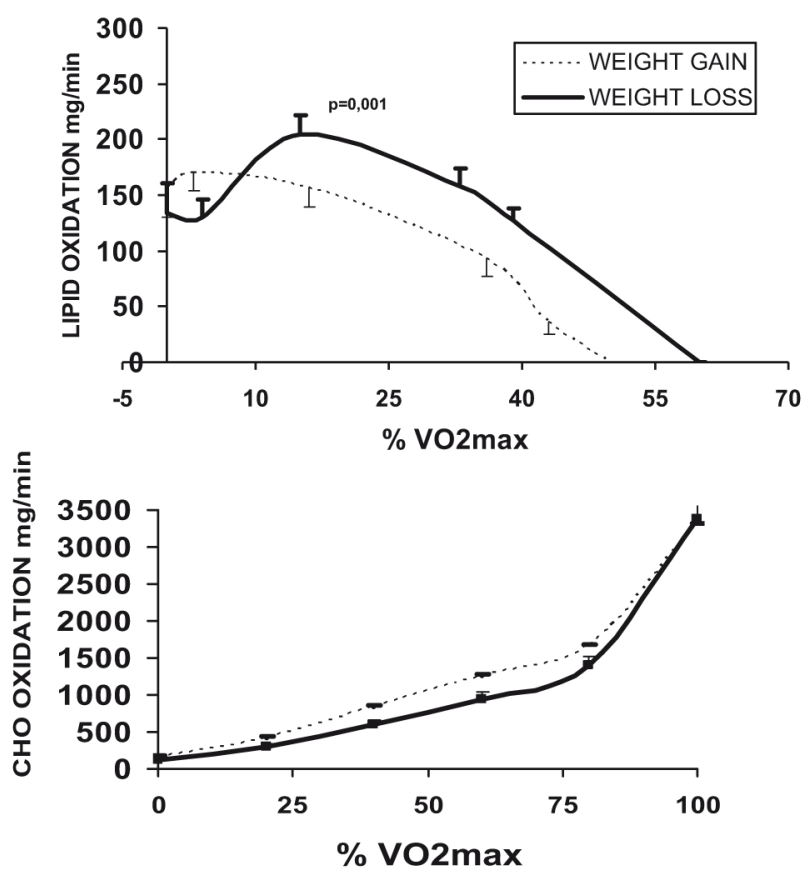

Figure 1 Comparison of the two profiles of lipid and carbohydrate $(\mathrm{CHO})$ oxidation during exercise plotted against exercise intensity in subjects gaining weight (dashed lines) or losing weight (full lines) when engaging into low weekly volumes of regular exercise.

value at $8.10 \pm 0.49$ vs $10.8 \pm 1.04 \mathrm{mg} / \mathrm{min} / \mathrm{kg}$ of muscle, $P<0.02)$ and shifted to lower power values $(36.43 \pm 2.64$ vs $47.16 \pm 4.77$ watts, $P=0.05$ ) in subjects gaining weight compared to those who lose weight during exercise. In addition carbohydrates become the only substrate used by the exercising muscle at an intensity which is significantly lower $\left(61.7 \pm 3.1 \%\right.$ vs $75.18 \pm 5.90 \%$ vs of $\left.\mathrm{VO}_{2 \max }, P<0.05\right)$ in subjects that gain weight.

All patients that gained weight during exercise were characterized by low weekly volumes of exercise $(2-3 \mathrm{hr} / \mathrm{wk})$ that were clearly targeted above the lipid oxidation zone. When asked why they exercised at such levels patients explained that by the counseling of sport coaches or by their personal belief of what is "sport"'. They describe feelings of increased hunger after exercise, with or without binge and nibbling. There were also anecdotal cases of exercise training performed immersed in water (swimming pool) which were also associated with increased hunger and gain weight.

\section{Discussion}

This study shows that a sample of individuals who gain weight when engaging into exercise training are characterized by:

- a lower ability to oxidize lipids at exercise with early predominance of $\mathrm{CHO}$ oxidation, when compared to matched subjects losing weight;

- low volumes of exercise targeted above the lipid oxidation zone; 
- increased feeling of hunger after exercise, resulting into nibbling. In addition, exercise performed immersed in water also results frequently into increased hunger.

Studies like STRRIDE [3] have shown that low volumes of physical activity paradoxically exhibit a better effect on body composition and carbohydrate homeostasis when they are targeted at a low to moderate intensity. The study "LIPOXmax Réunion" also shows that exercise targeted at the level of maximal lipid oxidation is as efficient to reduce weight and more efficient to reduce $\mathrm{HbA} 1 \mathrm{c}$ and to increase lipid oxidation than exercise targeted at a higher level [4].

Since the energy consumption of such low volumes of muscular activity is quite reduced, it is not likely to explain weight loss by its own. Actually training-induced changes in eating behavior probably play a major role in exerciseinduced weight loss, but this issue is complex because exercise exerts a dual effect on appetite. It may either increase the orexigenic drive or increase meal-induced satiety [5] and the combination of these two effects may be difficult to interpret.

It has been demonstrated that glycogen depleting exercise even when it does not induce a fall in blood glucose increases spontaneous food intake [6] according to Flatt's paradigm that eating behavior is under the dependence of homeostatic mechanisms aiming at the maintenance of stable glycogen levels, rather than toward the preservation of the overall energy balance [7].

Accordingly, we previously reported [8] that exercise performed at the level of maximal oxidation of lipids induces a gradual weight loss parallel to a decrease in nibbling and an increase in satiety, while exercise performed at the level where $\mathrm{CHO}$ become the exclusive fuel increased appetite and food intake.

When exercise is performed in water it appears to reduce more deeply blood glucose [9] so that training in a swimming pool may also be expected to be orexigenic. This may explain some paradoxical responses observed with protocols of training in water.

On the whole this study shows that subjects who actually gain weight during exercise training are those who oxidize more $\mathrm{CHO}$ and less fat during exercise, suggesting that this profile induces more glycogen depletion, which in turn increases appetite and food intake. Probably, the same level of exercise performed at high volume would result in a more important energy deficit that would be able to induce weight loss. However, at low volumes, increased calorie intake is more likely to overcome the energy deficit induced by exercise and thus result in positive energy balance and weight gain.

This study does not obviously imply that low volumes of exercise in such patients cannot induce weight loss. Since CHO wasting and glycogen depletion are likely to explain most of this paradoxical weight gain, individualized strategies involving shorter exercise bouts well targeted on lipids and minimizing $\mathrm{CHO}$ wasting can presumably be proposed in order to gradually enhance the ability to oxidize fat, which will in turn make low volumes of exercise become efficient for weight loss. Alternatively, higher volumes of exercise resulting in significant calorie loss whatever the fuel which is oxidized can be proposed.

The new and probably important finding of the current paper is that there is a phenotype of subjects prone to gain weight when exercising at low volumes, even more if they select high intensities that elicit massive $\mathrm{CHO}$ utilization.

It is important to identify such individuals when prescribing exercise for the management of obesity and to individualize for them the exercise protocol in order to avoid this unexpected paradoxical weight gain.

\section{Disclosure of interest}

The authors declare that they have no competing interest.

\section{References}

[1] Dutheil F, Lac G, Lesourd B, Chapier R, Walther G, Vinet A, et al. Different modalities of exercise to reduce visceral fat mass andcardiovascular risk in metabolic syndrome: the RESOLVE randomized trial. Int J Cardiol 2013;168:3634-42.

[2] Guiraudou M, Fédou C, Romain AJ, Sferlazza A, Calas E, Brun JF. Effects over one year of low-intensity endurance exercise targeted at the level of maximal lipid oxidation. Sci Sports 2015;30:e127-31.

[3] Slentz CA, Aiken LB, Houmard JA, Bales CW, Johnson JL, Tanner CJ, et al. Inactivity, exercise, and visceral fat. STRRIDE: a randomized, controlled study of exercise intensity and amount. J Appl Physiol 2005;99:1613-8.

[4] Besnier F, Lenclume V, Gérardin P, Fianu A, Martinez J, Naty $\mathrm{N}$, et al. Individualized exercise training at maximal fat oxidation combined with fruit and vegetable-rich diet in overweight or obese women: the LIPOXmax-Réunion randomized controlled trial. PLoS One 2015;10:e0139246.

[5] King N, Caudwell P, Hopkins M, et al. Dual-process action of exercise on appetite control: increase in orexigenic drive but improvement in meal-induced satiety. Am J Clin Nutr 2009;90:921-7.

[6] Melanson KJ, Westerterp-Plantenga MS, Campfield LA, Saris WHM. Appetite and blood glucose profiles in humans after glycogen-depleting exercise. J Appl Physiol 1999;87: 947-54.

[7] Flatt JP. The difference in the storage capacities for carbohydrate and for fat, and its implications in the regulation of body weight. Ann N Y Acad Sci 1987;499:104-23.

[8] Guiraudou M, Romain A-J, Mawunu M, Bedjih K, Fédou C, Brun $J-F$. Effets chroniques de l'exercice ciblé au niveau d'oxydation maximale des lipides (LIPOXmax) sur le comportement alimentaire de sujets obèses sédentaires. Sci Sports 2016;31:13-8.

[9] Pedro L, Vaillant G, Abbas R, Habchi M, Verret S, Sigonney $V$, et al. Effet de l'activité physique en milieu aquatique sur les glycémies au cours du diabète de type 2. Diabetes Metab 2014;40:A32. 